\title{
The incidence of poverty in Costa Rica between 1987 and 2017: stagnation or reduction? ${ }^{1}$
}

\author{
Andrés Fernández Aráuz and Ronulfo Jiménez Rodríguez
}

\begin{abstract}
According to official data (based on the income poverty line), $20 \%$ of households in Costa Rica were poor in 1994, a figure that has apparently not changed substantially since. The poverty level is currently considered to have stagnated at around $20 \%$ for more than two decades. However, the way poverty is measured has undergone methodological changes that preclude a strict comparison of the data over time. This study offers a method for dealing with the methodological difficulties and obtaining a set of comparable poverty data for the period from 1987 to 2017. It thereby demonstrates that the level of poverty in Costa Rica changed little between 1994 and 2006, but declined from the latter year onward.
\end{abstract}

\section{Keywords}

Poverty, income, households, household surveys, poverty mitigation, measurement, statistical methodology, Costa Rica

\section{JEL classification}

C13, C18, I3, P4

\section{Authors}

Andrés Fernández Aráuz holds a degree in Economics and a master's degree in Statistics from the University of Costa Rica. Email: affa17@gmail.com.

Ronulfo Jiménez Rodríguez holds a degree in Economics from the University of Costa Rica. Email: ronujimenez@gmail.com.

This paper was prepared for the Academy of Central America and financed by the Konrad Adenauer Stiftung. Its findings were published in November 2018. 


\section{Introduction}

Although various methods have been used to measure poverty in Costa Rica, the official measure, published annually by the National Institute of Statistics and Censuses (INEC), employs the income poverty line method. ${ }^{2}$

The income measurement carried out by INEC to estimate poverty levels was based on the Multipurpose Household Survey (EHPM) from 1976 to 2009 and has relied on the National Household Survey (ENAHO) since 2010.

According to official data, after the economic crisis that affected Costa Rica in the early 1980s, poverty fell to $20 \%$ of households in 1994 , and apparently has not moved substantially away from that level since. The poverty level is currently considered to have stagnated at around $20 \%$ for more than two decades (see figure 1).

Figure 1

Costa Rica: official figures for poverty and extreme poverty, 1980-2017

(Percentages)

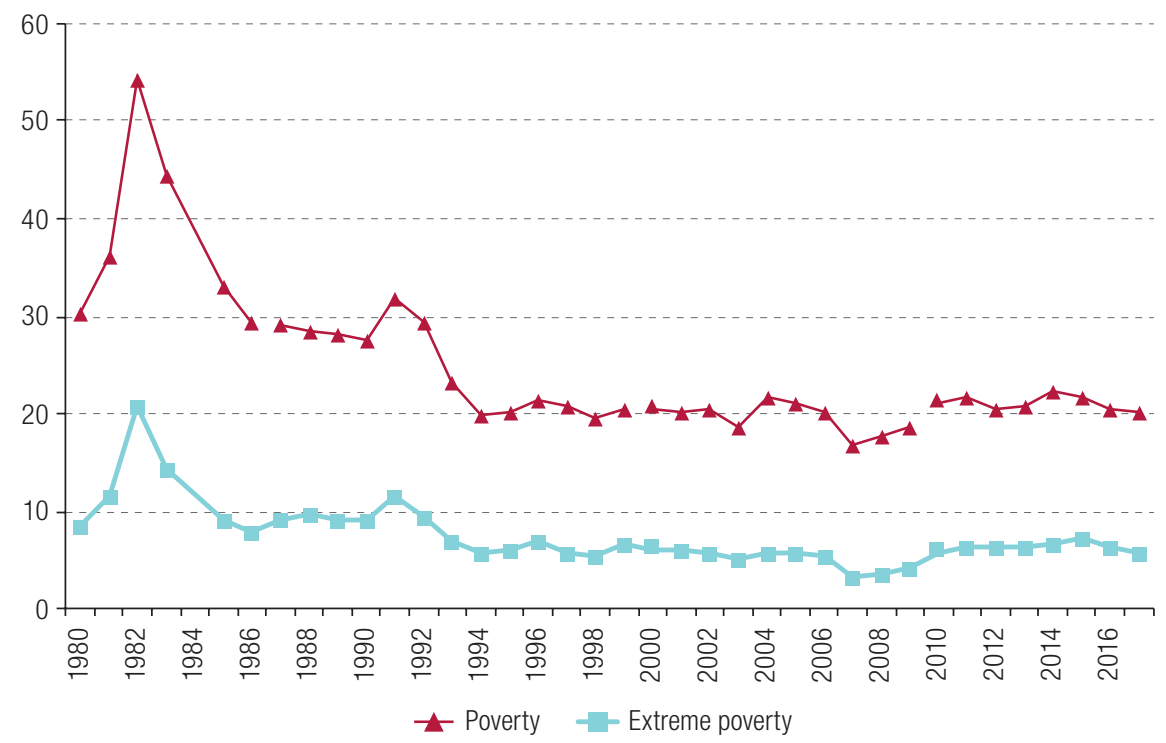

Source:P. Sauma and J. Trejos, "Evolución de la pobreza en Costa Rica: una revisión de las estimaciones 1980-1998", La pobreza en Costa Rica, Economic Science Research Institute (IICE), 2010, for the period from 1980 to 1986; National Institute of Statistics and Censuses (INEC), Multipurpose Household Survey (EHPM), for the period 1987-2009; and National Household Survey for the period 2010-2017.

However, the official method of measuring poverty in Costa Rica has four major limitations from the point of view of data comparability, three relating to the measurement of income and one to the measurement of the value of the poverty line, which hinder study of the long-term evolution of poverty.

Often these limitations are overlooked and the evolution of poverty over the last 30 years is discussed as though there were a comparable time series. In recent years, in fact, it has frequently been asserted that poverty reduction has stagnated, with claims such as the following:

The estimates yielded by the income poverty line approach indicate that, on average, one fifth of Costa Rican households are poor. Since 1994 there has been a period of

\footnotetext{
2 A version of the Multidimensional Poverty Index has recently been incorporated into the official measure. See INEC (2015a, 2015b and 2018) and Fernández and Del Valle (2017 and 2016).
} 
stagnation in which, with some variations in particular years (such as 2003 and 2007), the indicator has stood at 20\%. In 2016, a rate of $20.5 \%$ was recorded (PEN, 2017, p. 42).

In Costa Rica, the proportion of households living in poverty as calculated by the poverty line method has stood still at around 20\% since the last decade [referring to the period 2005-2015] (INEC, 2015b, p. 9).

The proportion of families living below the poverty line fell to $20 \%$ in the early 1990 s, but since then has held fairly steady with some ups and downs. In 2013, the poverty rate was $20.7 \%$ (Hidalgo, 2014).

These claims are based on the official poverty measurements.

The aim of this paper is to overcome these limitations by reconstructing the per capita household income series so that the different years can be compared and by reconstructing the value of the basic food basket and poverty line. The results of this exercise are revealing. When measurement is carried out with a comparable methodology for the whole period, the claim that the poverty rate stagnated between 1994 and 2017 proves to be incorrect. According to the findings of this study, two subperiods can be distinguished. In the first, from 1994 to 2006, the poverty rate, defined as the percentage of poor households relative to the total number of households in the country, remained stagnant. In the second, from 2006 to 2017, not only did the incidence of poverty fall, but extreme poverty and the proportion of vulnerable households also declined.

The present article is divided into six sections, including this introduction. The second section explains all aspects of the measurement and processing of income data in the context of the household surveys conducted by INEC in Costa Rica. The third section describes the creation and composition of the basic food basket and the poverty line used in the country. The fourth section explains the methodology applied to create eight poverty series that are comparable over time. The fifth section presents the results and the sixth and last section the conclusions.

\section{The measurement and processing of income data using household surveys}

The poverty line method requires the measurement of household income and the establishment of a threshold or line to distinguish poor households from non-poor households. In Costa Rica, INEC is responsible for conducting a household survey and for processing and publishing the statistical data collected.

Since 1976, INEC has conducted a household survey each July to obtain a variety of statistics on the population and households. It is the main source of information on the incidence of poverty and on housing conditions and services, among other topics (INEC, 2010a and 2010b). Over time, INEC has made alterations to the sample, the definitions of concepts and the methods used to measure the different variables, with a view to improving the way in which economic and social phenomena and changes in these are measured and captured. While this is positive, methodological changes can make it difficult to compare data over long periods of time.

A new cycle of the household survey programme began in 2010. It is called the National Household Survey (ENAHO) to mark the change from the Multipurpose Household Survey (EHPM) conducted until 2009. The ENAHO continues to be a multipurpose survey in which basic research topics predominate, including sociodemographic and housing characteristics, activity status, the employment characteristics of those in work, income from earnings and other sources, and poverty. However, there are important differences between the two surveys in the way income information is collected and processed, and these are detailed below. 


\section{Definition of income}

In general, income is very complex to measure. While some components are easy to quantify (monetary wages), others are more difficult (self-employment income). In addition, some income is received regularly and some sporadically, some in cash and some in kind.

Between 1976 and 1979, only wages were asked about in Costa Rica's EHPM. Subsequently, in the period 1980-1986, primary income, i.e., wages and income from business activities, was measured (Sauma and Trejos, 2010). Household surveys were modified again in 1987, when a larger sample than the one used until then was incorporated and the questionnaire (information-gathering instrument) was modified to adapt it to new definitions and changes in the information-gathering strategy. In the specific case of income, the definition and method of calculating primary income were modified in 1987, and transfers received by families began to be estimated. In 1991, capital income began to be measured as well.

Given the difficulty of establishing a common definition from 1976 onward, the poverty analysis in this study starts from 1987. The set of questions on income in the EHPM remained the same for 23 years (from 1987 to 2009). The ENAHO (2010-2017) differs from the EHPM in its broader coverage of wage income, its differentiation of self-employment income by sector of activity, and its closer specification of categories of income from property rents and regular transfers (INEC, 2010b).

Clearly, the way income data are collected differs greatly between the two surveys, so the analysis of total income (i.e., the sum total of all types of income) must be undertaken with extreme care, since many types of income captured in the new ENAHO did not appear in the old EHPM, and some data apparently collected in both surveys were not actually obtained via explicit questions in the EHPM, but were considered implicit in the answers provided by households.

The data for the 1987-2009 household income series are quite comparable in relative terms, because although there were several changes in the sampling frame, weights and stratification, these only affect the estimates of area or regional totals, while the estimates of relative figures (such as percentages) at the national level are perfectly comparable across years. Thus, the challenge is to bring the measurement of income in the new ENAHO into line with the old EHPM.

Currently, total household income as measured in the ENAHO comprises five major income sources, each of which is divided into different subcomponents. Of the 47 categories into which the income data currently collected can be broken down, only 19 were also included in the old EHPM, and even then not all of them were analysed in the same way. Thus, it is possible to calculate household income from 2010 to 2017, but excluding those categories that were not directly dealt with in the EHPM. Doing this will obviously result in a reduction of total household income owing to the exclusion of the new income categories included in the ENAHO.

In general terms, $88 \%$ of the total income captured by the new ENAHO is maintained at the national level, i.e., $12 \%$ of the income currently captured has to be left out in order for an income series that is comparable between periods to be obtained. However, the situation varies according to the initial income situation of each household. In the case of households in the tenth income decile, for example, only $85 \%$ of total income remains, while in that of households in the first income decile the figure rises to $95 \%$, which means that the effect is smaller for households with lower incomes (because their income sources are less diversified). The incomes of the poorest deciles, then, change by less. Leaving these incomes out of consideration in the calculation of total household income will necessarily affect the poverty levels estimated for each year. 


\section{Imputation of missing income}

The official poverty estimates derived from the EHPM (1987-2009) and the ENAHO (2010-2017) are not comparable because of the way missing or unreported income is treated.

Household surveys are administered to a representative sample of dwellings (and households) in the country. It may happen that the interviewer is unable to administer the questionnaire to a particular household because the respondent cannot be located or declines to take part. In this case, the household has to be replaced by another from which the information is forthcoming. It may also happen that the respondent agrees to the interview but is unable or unwilling to provide information on the incomes of some or all of those in receipt of them in the household. In cases where there are recipients with unknown incomes, the household is classified in the "income unknown" category.

When this happened in the EHPM framework between 1987 and 2009 and no actual measured income was available, INEC calculated poverty levels by excluding these households, i.e., the poverty line method was applied only to households with known incomes. The practice of excluding households with unknown incomes limits or precludes inferences regarding the total population, unless it can be assumed (implausibly) that the distribution of the missing data is completely random.

In the case of the new ENAHO (2010-2017), households with unknown incomes are incorporated by means of an imputation method whereby an income level is assigned to these households (conditional means). In the ENAHO, the proportion of households in which at least one income-receiving household member does not declare his or her income is around 6\%. If the methodology used from 1987 to 2009 to estimate poverty were to be applied in this survey, but excluding households with unknown incomes, poverty levels would be higher than those officially estimated in all years. Moreover, the larger the percentage of households with missing income values, the greater the difference will be between the official poverty estimate and the unofficial estimate (which excludes these households).

This is because less than a tenth of all households to which at least one type of income is imputed are ultimately classified as poor, so that the greater the number of households that income has to be imputed to, the fewer poor and the more non-poor households will be proportionately obtained. This last idea must be interpreted with great care. The fact that most of the households to which income is imputed in the INEC databases are classified as non-poor implies that, in general, it is members of betteroff households who do not report some of their income (since the imputation method estimates the level of income for persons with similar characteristics in respect of sex, education level and occupation). If this assumption were to hold for the period 1987-2009, it could be concluded that the official poverty estimates for those years were overestimates. In other words, if income were imputed to households where there are missing values (instead of these being excluded), the poverty level would be lower throughout the series. While a mean $20 \%$ of households were excluded from the poverty estimates in the 1987-1993 series, this proportion fell to 13\% in the period 1994-2004 and to 7\% in the period 2005-2009.

This means that the difference between the poverty rate estimated with the official methodology and that based on the imputation of unknown income is not constant over the period 1987-2017. The poverty rate estimates with imputation of unknown income would decrease the most relative to the official estimate in the period 1987-1993, while the 2005-2009 series would show the least change relative to the official series.

When these estimates were made, evidence was found to support the above contentions: the difference between the official poverty levels and the imputed figures is $-15 \%$ for the period 1987-1993, -9.4\% for the period 1994-2004 and -4.8\% for the period 2005-2009. Accordingly, in order to methodologically standardize the estimation of household incomes with regard to unknown incomes for the whole period 1987-2010, the conditional mean imputation method used in the period 2010-2017 will be applied to the EHPM for the years 1987-2009, as explained in the methodology section. 


\section{Underdeclaration of income}

While it is possible for households to provide income information for all recipients, in some cases respondents tend to underreport the amount of income received, i.e., for various reasons they declare incomes lower than those actually received by the household. For this reason, when income information from a survey is used, the dilemma arises as to whether to use the income amounts reported, even if they are suspected to be lower than the amounts actually received, or to adjust them to reduce or eliminate the underreporting effect.

In both the EPHM (1987-2009) and the ENAHO (2010-2017), INEC has favoured the second option, adjusting reported income by multiplying it by a coefficient. However, the adjustment criterion has been different in the two periods. In the EHPM (1987-2009), INEC adjusted the per capita income of urban and rural households differently, with reported income being multiplied by a coefficient of 1.174 for urban households and 1.358 for rural households (INEC, 2002). In other words, the per capita income of each household was increased by between $17 \%$ and $35 \%$ to arrive at the final calculation of the poverty level in the population (INEC, 2004). In the ENAHO (2010-2017), the coefficients are obtained by comparing the estimated incomes with the Central Bank's System of National Accounts by income source. In particular, the following types of income are adjusted (INEC, 2018): (i) agricultural wage income (coefficient of 1.59); (ii) non-agricultural wage income (1.30); (iii) agricultural self-employment income (1.60); (iv) non-agricultural self-employment income (1.30); (v) property rental income (2.08). All other forms of income (not mentioned) are unadjusted.

Not only are the values of the coefficients different, but so is their application by geographical area and income type: whereas before 2010 per capita income was adjusted by a single coefficient according to the type of household, so that the same coefficient was applied to all types of income, since that year the adjustment has no longer been applied to per capita income but to each type of income separately, and not to all types of income. A priori, it is not possible to know which of the two methodologies produces the largest income adjustment, since although the new coefficients applied in the ENAHO are higher than those used previously, they are only applied to some types of income (for example, transfers are not adjusted), while in the EHPM the coefficient was implicitly applied to all types of income (via per capita income).

In conclusion, adjustments for underreporting make it impossible to compare measurements of income and the incidence of poverty between the two periods. For this reason, two income series are used alternatively in the present study. One of them is adjusted for the entire period 1987-2017 using the income underreporting criterion applied in the period 1987-2009. Since it is not possible to adjust incomes for the whole period using the criterion applied between 2010 and 2017, as the way the information is disaggregated in the databases for the period 1987-2009 does not allow it, the other series is not adjusted in any way for underdeclaration, i.e., it includes incomes as declared by informants.

\section{Poverty lines}

As mentioned above, measuring poverty using the poverty line method requires household income to be compared with a minimum threshold or line so that households can be classified as poor or non-poor.

This section analyses the criteria applied by INEC in the official methodology to measure the basic food basket and the poverty line in the period 1987-2017 and proposes a way to achieve a uniform measurement of these concepts and allow comparison to be carried out in the period. 


\section{The poverty line and the basic food basket}

The basic concept of the poverty line is one of the oldest in applied economics, having been known since at least the eighteenth century (Ravallion, 2016). Even before the establishment of poverty measures for descriptive purposes, attempts had already been made to establish a minimum level of income above which people were not to be considered poor for policy purposes.

The conception of poverty applied has ranged from concepts of welfare or utility to the measurement of gross domestic product (GDP) as a proxy. However, the availability of robust poverty measures using different criteria dates back only a few decades. While this has led to the development of several very different ways of measuring poverty in the literature, the present study focuses on the most widely used global measure, based on household income and known as the poverty line method.

The poverty line is defined in economics as the cost of obtaining a given level of economic well-being or standard of living in a given place and period (Ravallion, 2016). This definition depends on the cost-of-living index (or basic food basket) used to determine the level of well-being or standard of living taken as the benchmark.

The key idea of poverty lines is that the benchmark represents the minimum level of economic well-being necessary to not be considered poor. In Costa Rica, the official method involves the calculation of a poverty line that represents the minimum amount of income required for a household to have sufficient resources to meet the basic needs of its members (INEC, 2004).

For the period 1987-2017, two basic food baskets and, consequently, two poverty lines were used. The first, called the CBA-1995, was used for the period between 1987 and 2009, and the second, the CBA-2011, for the period between 2010 and 2017. Although the methodology of the two poverty lines is broadly similar, some details imply differences in their construction. For example, while the CBA-1995 was constructed in 1995 on the basis of the 1988 household expenditure structure, the CBA-2011 was constructed in 2011 on the basis of the 2004 household expenditure and consumption structure. Moreover, the CBA-2011 includes a larger quantity of food than the CBA-1995, although paradoxically it provides for a lower minimum calorie requirement (2,184 as against 2,230 in urban areas).

INEC began calculating the value of the CBA-2011 in 2004, as its construction was based on that year's National Household Income and Expenditure Survey (ENIGH). This made it possible to compare the basic food basket and the poverty line established with the two methodologies for the years 2004-2009. It is observed that the values of the basic food basket and the poverty line based on the 2011 methodology are higher than with the 1995 methodology. In other words, the methodological change entails more demanding thresholds for determining which households are poor and which are not. On average, in the period 2004-2009, the CBA-2011 cost 13\% more than the CBA-1995 in urban areas and $7 \%$ more in rural areas. These changes are reflected to a greater degree in the value of the poverty line, because the 2011 methodology involved the application of higher coefficients to get from the basic food basket to the poverty line. ${ }^{3}$ The poverty line was 37\% higher in urban areas and 25\% higher in rural areas with the 2011 methodology than with the 1995 methodology.

It is important to recall that INEC needed to make the methodological change to update the definition of poverty thresholds. As was to be expected, given the improvement in general living conditions in the country, monetary values for the basic food basket and the poverty line were higher under the new methodology than the previous one. While the official INEC estimate of the poverty rate for the period 2004-2009 was based at the time on the CBA-1995, it is clear that the poverty rate estimates would be higher if the CBA-2011 were used for the same years. In other words, the methodological

\footnotetext{
3 In the CBA-1995, INEC applied the Engel coefficient to calculate the value of the poverty line, while in the CBA-2011 it used the Orshansky coefficient. The latter is the inverse of the Engel coefficient, which measures the share of food expenditure in total expenditure.
} 
change has consequences for the estimated level of poverty and means that two periods in which the methodology for estimating the basic food basket and the poverty line are different cannot be compared.

In conclusion, two different baskets have been used to measure poverty in the period 1987-2017, each reflecting the consumption pattern prevailing in the year concerned. This differentiation has resulted in different levels of poverty being estimated for the country. A single series of comparable data on the value of the basic food basket and the poverty line for the whole period could be obtained by taking the CBA-1995, maintaining its composition and continuing to calculate its value with the prices observed in the period 2010-2017, or by taking the CBA-2011, maintaining its composition and estimating its value with the prices observed between 1987 and 2009. Unfortunately, both options are unfeasible, because the data for some goods in the old basket ceased to be collected after the methodological change and the prices of some goods in the new basket were not collected before it.

Given this impossibility, another way is to "splice" the value of the two baskets by measuring the growth in their current value. For this, it is important to find out whether they underwent similar changes in a period for which estimates of the value of both baskets are available simultaneously, i.e., between 2004 and 2009. There were no major differences in the trends in those years, but rather a great similarity in the values for some years. This means that, although the structure and composition of the basic food basket differ between the CBA-1995 series and the CBA-2011 series, the relative growth in the prices of goods and services within each basket has been similar. Assuming the same behaviour for the other years of the time series analysed in this paper, it is possible to simulate the value of the CBA-1995 in the period 2010-2017 and the value of the CBA-2011 in the period 1987-2003, thus obtaining two long-term poverty series that are comparable over time.

\section{Methodology}

The objective of this section is to construct a series of comparable data on the evolution of poverty in Costa Rica over the period 1987-2017. This is done by starting from the official series and making the necessary adjustments to be able to compare the different measures of income and the poverty line and thus overcome the comparability limitations pointed out in the previous sections.

As mentioned above, the poverty estimates made by INEC from 1987 to 2017 are not strictly comparable in several subperiods, owing to changes in the measurement of income (definition of income, treatment of unknown incomes and adjustments for underreporting of income) and in the composition and valuation of the basic food basket and the poverty line. These changes are summarized in table 1.

Table 1

Costa Rica: main changes in the poverty measurement methodology of the National Institute of Statistics and Censuses (INEC)

\begin{tabular}{|c|c|c|}
\hline Obstacles to comparison & $\begin{array}{l}\text { Multipurpose Household Survey } \\
\text { (EHPM), 1987-2009 }\end{array}$ & $\begin{array}{l}\text { National Household Survey } \\
\text { (ENAH0), 2010-2017 }\end{array}$ \\
\hline \multicolumn{3}{|l|}{ For income } \\
\hline Measurement of household incomes & Nineteen income types are monetized & Forty-seven income types are monetized \\
\hline $\begin{array}{l}\text { Treatment of households whose } \\
\text { incomes are unknown }\end{array}$ & Not imputed (excluded) & Imputed (included) \\
\hline Adjustment for underdeclaration of income & $\begin{array}{l}\text { Applies to per capita income (all } \\
\text { income types), with a distinction } \\
\text { between urban and rural areas }\end{array}$ & $\begin{array}{l}\text { Applies to some income types (not all), } \\
\text { with no distinction between areas }\end{array}$ \\
\hline \multicolumn{3}{|l|}{ For the basic food basket and poverty line } \\
\hline Value of the basic food basket and poverty line & $\begin{array}{l}\text { The } 1995 \text { basic food basket is used } \\
\text { (National Household Income and } \\
\text { Expenditure Survey (ENIGH) 1988) }\end{array}$ & $\begin{array}{l}\text { The } 2011 \text { basic food basket } \\
\text { is used (ENIGH 2004) }\end{array}$ \\
\hline
\end{tabular}

Source: Prepared by the authors. 
The objective of this study is to estimate a long-term poverty data series for Costa Rica that is comparable at all points. To this end, the previous sections analysed the factors that hamper comparability and proposed different methods for dealing with these limitations and observing the evolution of poverty over time.

Because the objective is to analyse poverty trends rather than levels, eight poverty series will be estimated by combining factors that ensure standardization and comparability for the entire period analysed, as detailed in table 2 .

Table 2

Details of the construction of eight poverty series that are comparable in the long term

\begin{tabular}{|c|c|c|c|c|}
\hline $\begin{array}{l}\text { Reconstructed } \\
\text { poverty series }\end{array}$ & Income structure & Imputation & $\begin{array}{l}\text { Value of the basic food } \\
\text { basket and poverty line }\end{array}$ & $\begin{array}{l}\text { Adjustment for } \\
\text { underdeclaration of income }\end{array}$ \\
\hline Poverty series 1 & \multirow{8}{*}{$\begin{array}{l}\text { Multipurpose Household } \\
\text { Survey (EHPM) }\end{array}$} & \multirow{4}{*}{$\begin{array}{l}\text { Not imputed (as } \\
\text { per the EHPM) }\end{array}$} & \multirow{2}{*}{$\begin{array}{l}\text { CBA-1995 (National Household } \\
\text { Income and Expenditure } \\
\text { Survey (ENIGH) 1988) }\end{array}$} & No adjustment \\
\hline Poverty series 2 & & & & Adjustment as per the EHPM \\
\hline Poverty series 3 & & & \multirow[t]{2}{*}{ CBA-2011 (ENIGH 2004) } & No adjustment \\
\hline Poverty series 4 & & & & Adjustment as per the EHPM \\
\hline Poverty series 5 & & \multirow{4}{*}{$\begin{array}{l}\text { Imputed (as per the } \\
\text { National Household } \\
\text { Survey (ENAHO)) }\end{array}$} & \multirow[t]{2}{*}{ CBA-1995 (ENIGH 1988) } & No adjustment \\
\hline Poverty series 6 & & & & Adjustment as per the EHPM \\
\hline Poverty series 7 & & & \multirow[t]{2}{*}{ CBA-2011 (ENIGH 2004) } & No adjustment \\
\hline Poverty series 8 & & & & Adjustment as per the EHPM \\
\hline
\end{tabular}

Source: Prepared by the authors.

As can be seen, only the income series with the EHPM income structure can be used, which means adjusting the ENAHO income results downward (and making poverty look higher in the period 2010-2017). Both the methods for dealing with unknown incomes (not imputing and imputing) will be applied.

The conditional means method is used to impute income, consisting in the formation of categories from covariates correlated with the variable of interest and the imputation of missing data with observations from the subsample that shares common characteristics (Acock and Demo, 2005; Medina and Galván, 2007). In this method, missing data are assumed to follow a missing completely at random (MCAR) pattern and there will be as many averages as there are categories formed. This helps to mitigate biases in each cell. In this specific case, the conditioning variables used in the imputation process are "area of residence", "sex", "education" and "occupation". Imputation is performed on the main income, secondary income and other household income.

Poverty levels will be simulated under the conditions described using the two series of values for the basic food basket reconstructed with and without adjustment for underdeclaration of income. All this will yield eight poverty series that are different from each other, but methodologically comparable over the whole period.

The objective is to analyse the long-term trend of these eight poverty series to determine whether the incidence of poverty in Costa Rica has stagnated or changed over the last three decades. Since this is not a stationary time series (serial autocorrelation is significantly positive), the method used to understand whether the trends obtained from the poverty series estimates differ from the official series is to compare the slopes of the regression lines predicted by calculating a bivariate linear regression.

This regression estimates the slope of the model $P_{t}=\beta_{0}+\beta_{1} A_{t}+\varepsilon$, where $P_{t}$ is the percentage of poverty in year $t, \beta_{0}$ is the intercept of the regression line, $\beta_{1}$ is the value of the slope of the line over year $A_{t}$, and $\varepsilon$ is an error term. The model estimation is carried out on standardized variables so as to obtain standardized coefficients as a measure of effect size and comparison between the different models. 


\section{Results}

While the period analysed runs from 1987 to 2017 (31 years of observations), some specialists argue that the level of poverty (according to the official income poverty line measure) has remained relatively unchanged since 1994. This often results in statements such as "poverty has stagnated at around 20\%" or "poverty has remained unchanged for the last two decades". Methodological changes implemented in the period under study can be expected to affect the recorded level of poverty and its long-term trend because, as demonstrated in the previous sections, methodological considerations have large effects on the measurement of income, the basic food basket and the poverty line.

The methodology described in the previous section was used to estimate eight different but methodologically comparable poverty series that enabled the evolution of poverty in the period 1987-2017 to be analysed.

While it is not possible to compare individual values, it is possible to compare the trends observed from these estimates with that derived from the official poverty figures estimated by INEC. Since this is not a stationary time series (serial autocorrelation is significantly positive), the method used to understand whether the trends obtained with the estimated poverty series are different from those yielded by the official series is to compare the slopes of the regression lines predicted by computing a linear regression, but showing the slope as the standardized coefficient obtained from the regression fit accompanied by its statistical significance ( $\mathrm{p}$-value) and the goodness-of-fit value (R-squared) of this bivariate model, taking into consideration only the period 1994-2017, as it is since 1994 that poverty is considered not to have shown substantial improvements.

For a better understanding of the procedure, the value of the slope and R-squared for the official poverty series estimated by INEC for the period 1994-2017 is shown below (see figure 2).

Figure 2

Costa Rica: poverty incidence estimated by INEC (official) and slope of the regression line, 1994-2017

(Percentages)

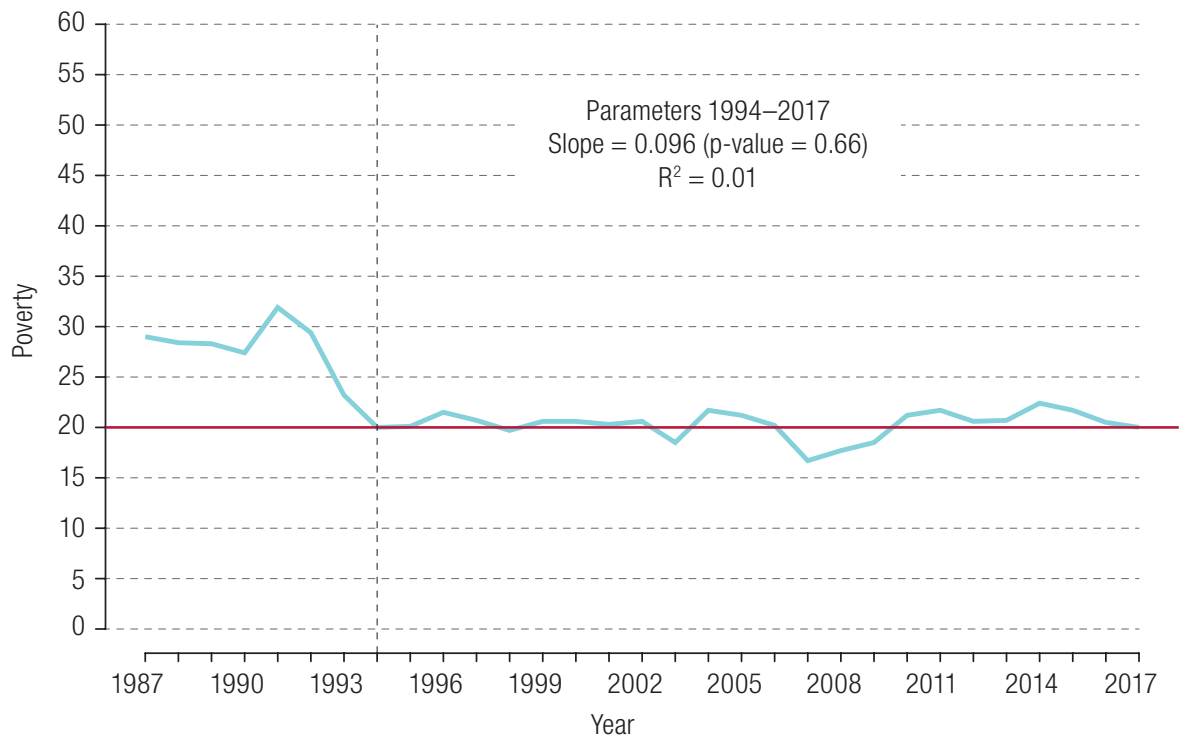

Source: Prepared by the authors, on the basis of figures from the National Institute of Statistics and Censuses (INEC) of Costa Rica. 
As can be seen in figure 2, the incidence of poverty between 1994 and 2017 does not vary significantly from 20\% (horizontal red line).

When a bivariate linear regression is estimated, it is observed that the slope of the poverty series from 1994 to 2017 is not statistically different from 0, as the Wald statistic is much higher than the values of $0.01,0.05$ and 0.10 that are usually used as parameters for comparison. This means that when the poverty time series officially estimated by INEC from 1994 to 2017 is analysed without taking into account the impossibility of comparing the data that make it up, it is indeed found not to have changed over time, i.e., to have been "stagnant" for the last 23 years. This type of analysis is the error that the present study attempts to rectify. Following the same logic, the poverty series estimated in this study are shown below (see figure 3 and the numerical data in annex A1).

\section{Figure 3}

Costa Rica: estimated poverty series that are comparable for the period 1987-2017 (Percentages)

\section{A. Poverty series 1}

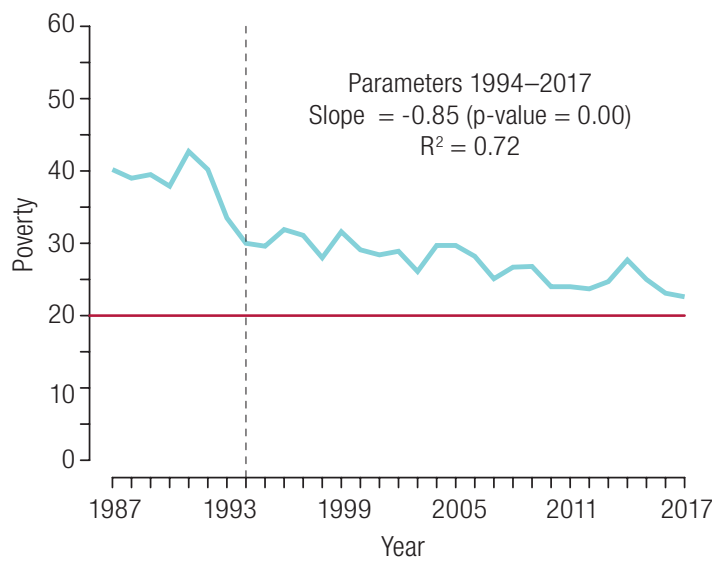

C. Poverty series 3

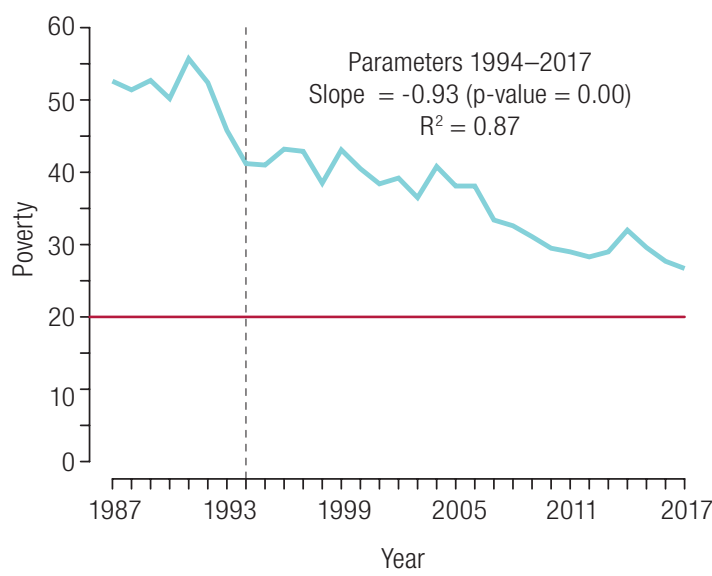

\section{B. Poverty series 2}

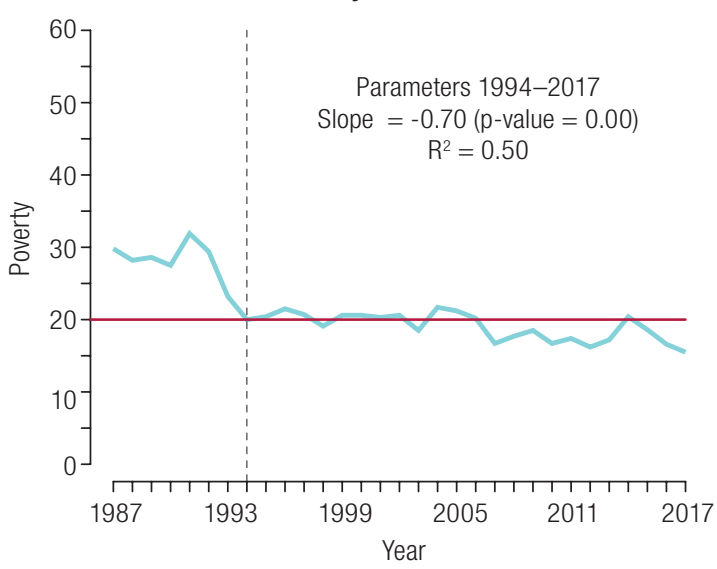

D. Poverty series 4

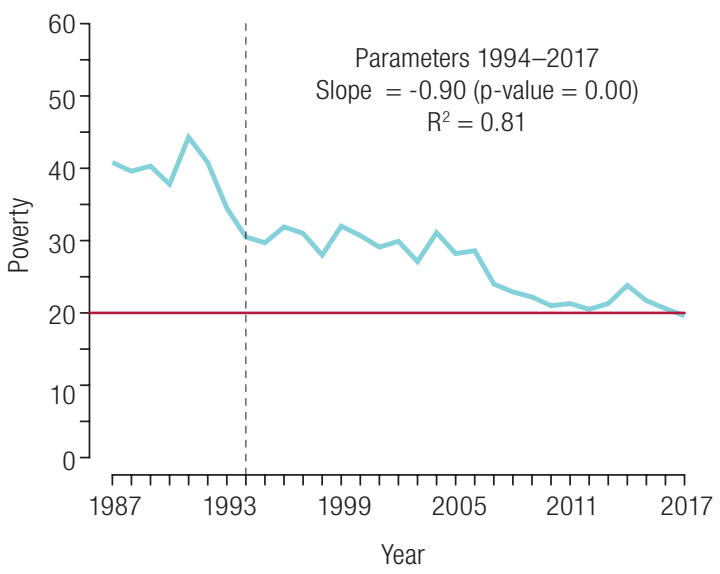


Figure 3 (concluded)

E. Poverty series 5

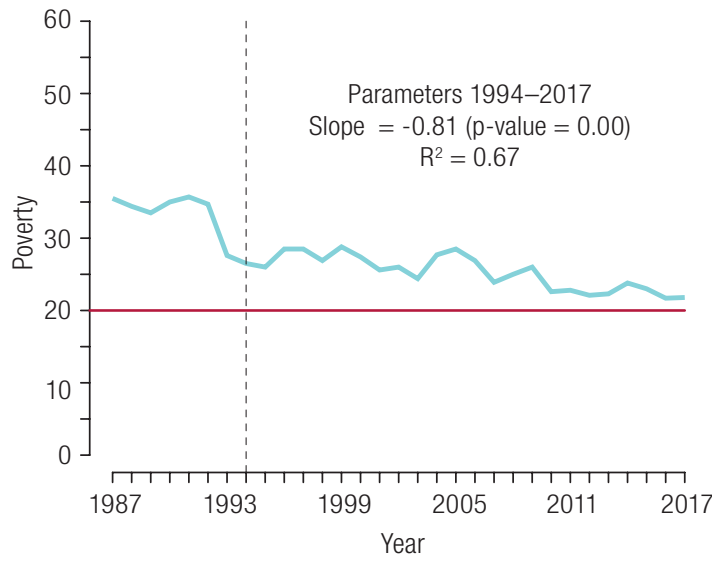

G. Poverty series 7

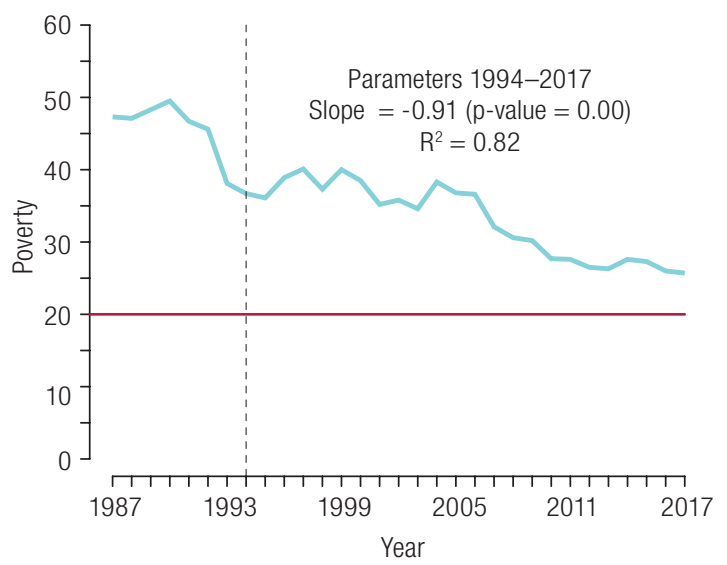

F. Poverty series 6

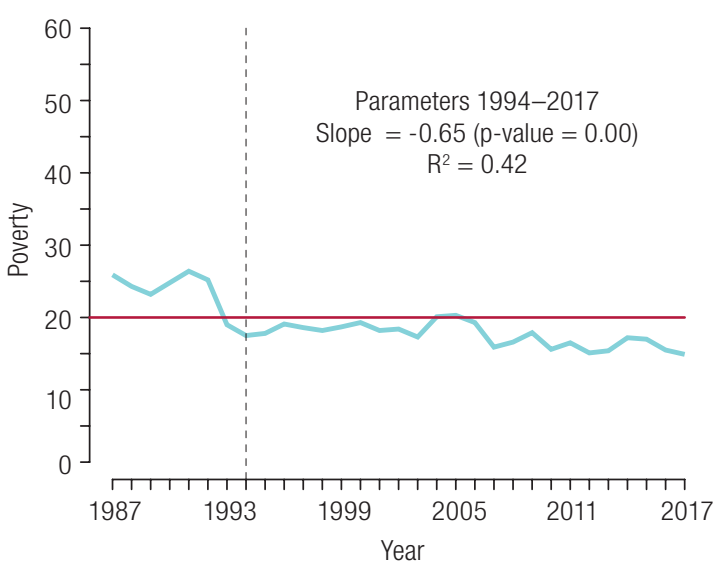

H. Poverty series 8

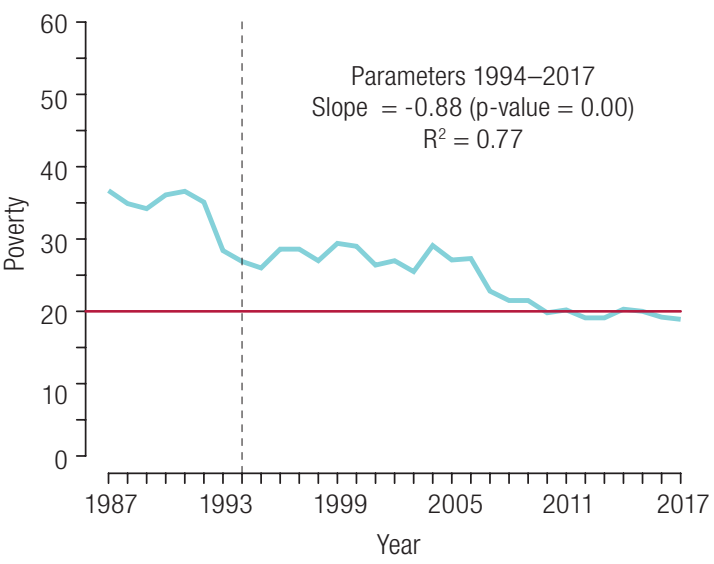

Source: Prepared by the authors, on the basis of figures from the National Institute of Statistics and Censuses (INEC) of Costa Rica.

Figure 3 shows the evolution of poverty in Costa Rica between 1994 and 2017 according to the eight series estimated. Visually, a decreasing trend can be seen in all eight panels, and this trend is statistically confirmed by observing that the slope of the estimated regression line for each of the eight series is negative, statistically different from 0 ( $p$-value below 0.01 ) and of considerable effect, as the standardized coefficients can only vary between 0 and 1 (absolute value), and for four of the time series estimated the estimated slopes are higher than 0.75 (absolute value).

This result shows that, when poverty series based on data that are comparable over time are used, there has been a reduction in poverty over the last 30 years, including the period that has generated the most criticism (from 1994 onward).

Once again, it is important to bear in mind that each of these eight series is different from the others, as they are all produced by combining the parameters that originally rendered the data of the official series non-comparable. However, the underlying data are indeed comparable within each series, as the same methodology is applied throughout the period.

In conclusion, poverty in Costa Rica fell over the period 1994-2017, as evidenced by the analysis using comparable data series for income, the basic food basket, adjustment for underreporting and income imputation. However, an even closer study of the data reveals different patterns over the 31 years 
of analysis. Given the changes in poverty in the eight series, it is possible to distinguish four subperiods, going by the record of significant changes in poverty rates. Thus, similar behaviours are observed in the years within four subperiods, namely 1987-1992, 1992-1994, 1994-2006 and 2006-2017.

To convey what happened in these subperiods, the above analysis is replicated exactly, with estimates of bivariate regressions and analysis of the value of the standardized coefficient of the regression (the magnitude of the effect) and the statistical significance of this coefficient. These results are shown in annex A2. The main conclusion is that before 1994 there was an initial period when poverty stagnated (1987-1992), followed by a sharp decline that lasted only two years (1992-1994). A new period of stagnation began in 1994 and lasted for 12 years, then a period of sustained poverty reduction began in 2006, lasting until 2017.

This means that the reduction in poverty in the period 1994-2017 was mainly due to the influence of what happened between 2006 and 2017, as there were no major variations in the trend between 1994 and 2006.

\section{Brief characterization of households by poverty status}

To study the evolution of poverty more thoroughly, the population was divided into four groups with a view to examining their main characteristics. These groups are households in extreme poverty, households in non-extreme poverty, vulnerable households and non-poor households. The analysis is based on one of the comparable poverty data series included in table 2 (series 8).

Households in extreme poverty are those whose adjusted per capita income is below the value of the reconstructed 2011 basic food basket. Households in non-extreme poverty have a per capita income higher than the value of the reconstructed 2011 basic food basket but lower than or equal to the value of the reconstructed 2011 poverty line. Lastly, vulnerable households are those which are not poor but whose income is at most $30 \%$ higher than the value of the corresponding poverty line, so that they are at risk of entering the group of poor households.

Figure 4 shows that in the years following the crisis of the 1980s, specifically in 1987, poverty affected $37 \%$ of the country's households, a proportion which rises to $48.5 \%$ when vulnerable households are included. In other words, almost half the country's households were poor or very close to it.

In the period 1987-1992, there were no significant changes in the household structure classification by poverty status.

Between 1992 and 1994, a period of only two years, the proportion of households in extreme poverty and non-extreme poverty fell by 4.2 percentage points each. Although the causes of this dramatic reduction have been little studied, it is believed to be associated with strong national income growth, as this was over $6 \%$ per annum.

In the period 1994-2006, there were no substantial changes in the incidence of poverty, extreme poverty or vulnerability. In this period, national income growth was generally below $4 \%$.

The period 2006-2017 shows a reduction in the incidence of poverty, as the proportion of households in situations of extreme poverty, non-extreme poverty and vulnerability decreases and the proportion of households not affected by poverty increases accordingly (see figure 4). Poverty declined particularly in 2007, when national income growth was above $6 \%$.

Thus, the level of poverty in Costa Rica was 48\% lower in 2017 than in 1987 or, if the comparison is made with the 1990s (when the so-called "stagnation of poverty" began), the country was $30 \%$ less poor than in 1994. This achievement is unquestionably even more significant when it is considered that the largest reduction was in households in extreme poverty, whose proportion of the total in 2017 was less than half what it had been in 1987. 
Figure 4

Costa Rica: classification of households by poverty status (series 8), selected years (Percentages)

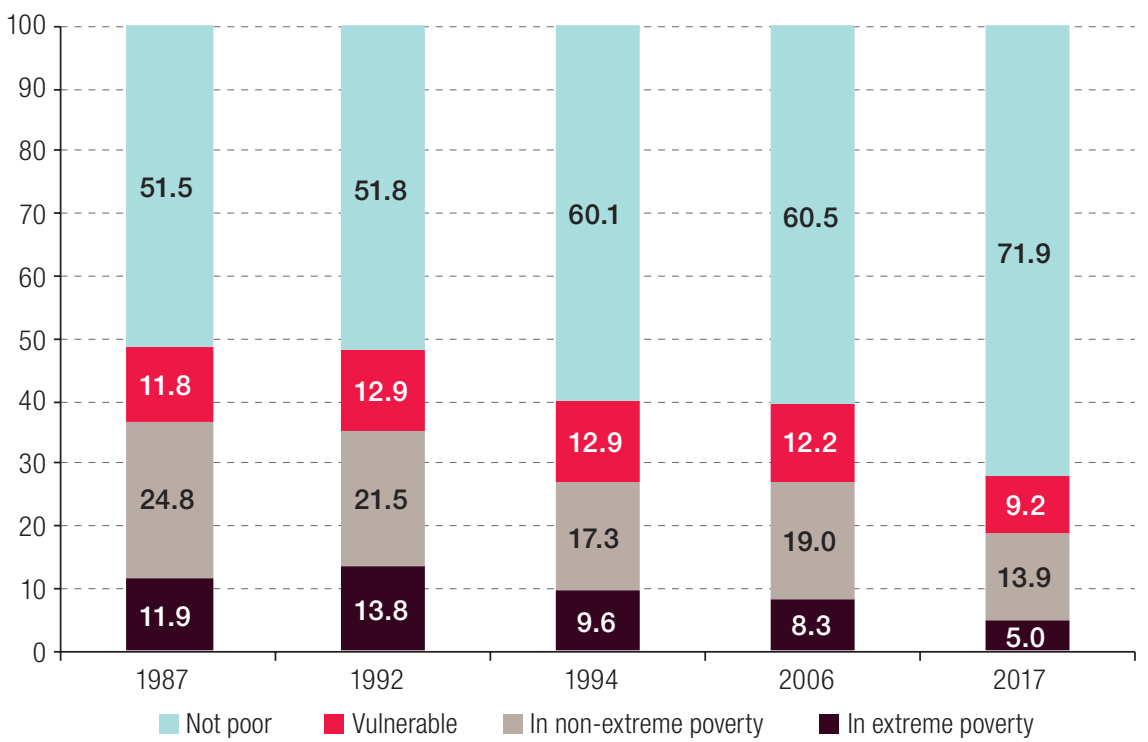

Source: Prepared by the authors, on the basis of figures from the National Institute of Statistics and Censuses (INEC) of Costa Rica.

As regards the incidence of poverty among different subpopulations, one of the main focuses is on differences according to the sex of the household head. While the majority of poor households are headed by men (80\% in 1987 and 54\% in 2017), poverty affects female-headed households more, and particularly households headed by women who do not have a partner (lone female heads of household).

While the estimated poverty level in 2017 was around 18\% nationally, this proportion increased to $24 \%$ for lone female heads of household. This trend is observed throughout the period under review (see table 3).

This is no minor issue, and it takes on particular importance when changes in the family structure of poor households are analysed. Between 1987 and 1994, about 70\% of poor households were headed by men with partners, while only $2 \%$ were headed by women with partners. The second largest group was women without partners (lone female heads of household), who accounted for $19 \%$.

This structure changed in 2017, with the proportion of poor male-headed households decreasing and the proportion of households headed by single women doubling. Considering that this is the very group with the highest historical incidence of poverty, it is clear that single female-headed households are much more vulnerable than any other type of household.

Education is another factor strongly associated with the probability of being poor. In fact, the educational environment of a household, defined as the average number of years of education of the adults living there, is a variable with high predictive power for poverty. In Costa Rica, an average of less than 6 years' education (incomplete primary) is considered low, an average of between 6 and 11 years is considered medium and an average of 11 years and over (complete secondary or better) is considered high.

Figure 5 shows the percentage of households with low education by poverty status. Thus, in 1987, almost $80 \%$ of households in extreme poverty and about $70 \%$ of households in non-extreme poverty had a low level of education. Although non-poor households are less affected by educational problems, half of these households also had a low level of education in 1987. 
Table 3

Costa Rica: incidence of poverty in different categories of households, 1987-2017 (Percentages)

\begin{tabular}{lrrrrr}
\hline Characteristic & 1987 & 1992 & 1994 & 2006 & 2017 \\
\hline Sex and conjugal situation of household head & & & & & \\
\hline Male (with partner) & 68.1 & 69.1 & 70.8 & 61.6 & 46.2 \\
\hline Male (no partner) & 12.2 & 10.2 & 8.5 & 5.9 & 8.4 \\
\hline Female (with partner) & 1.1 & 2.4 & 1.9 & 3.2 & 8.2 \\
\hline Female (no partner) & 18.7 & 18.4 & 18.8 & 29.3 & 37.3 \\
\hline Age group of household head & & & & & \\
\hline Under 40 (young) & 35.4 & 39.1 & 30.0 & 30.3 & 21.5 \\
\hline 40 to 60 (intermediate) & 31.3 & 32.2 & 23.7 & 24.0 & 16.8 \\
\hline 60 or over (older) & 40.6 & 40.6 & 34.5 & 33.8 & 19.6 \\
\hline Planning region & & & & & \\
\hline Central & 29.5 & 33.2 & 23.5 & 24.1 & 15.6 \\
\hline Chorotega & 59.4 & 51.5 & 44.1 & 42.3 & 20.5 \\
\hline Pacífico Central & 43.2 & 41.9 & 33.5 & 36.4 & 28.4 \\
\hline Brunca & 48.0 & 51.6 & 44.3 & 39.7 & 26.3 \\
\hline Huetar Atlántica & 33.2 & 29.2 & 29.0 & 29.3 & 24.2 \\
\hline Huetar Norte & 42.1 & 40.3 & 32.9 & 31.0 & 23.4 \\
\hline Type of area & & & & & \\
\hline Urban & 30.9 & 29.7 & 24.4 & 26.6 & 19.0 \\
\hline Rural & 40.8 & 39.4 & 33.0 & 30.5 & 18.7 \\
\hline Source: Proan & & & & \\
\hline
\end{tabular}

Source: Prepared by the authors, on the basis of poverty series 8 .

Figure 5

Costa Rica: distribution of households with low education by poverty status, selected years (Percentages)

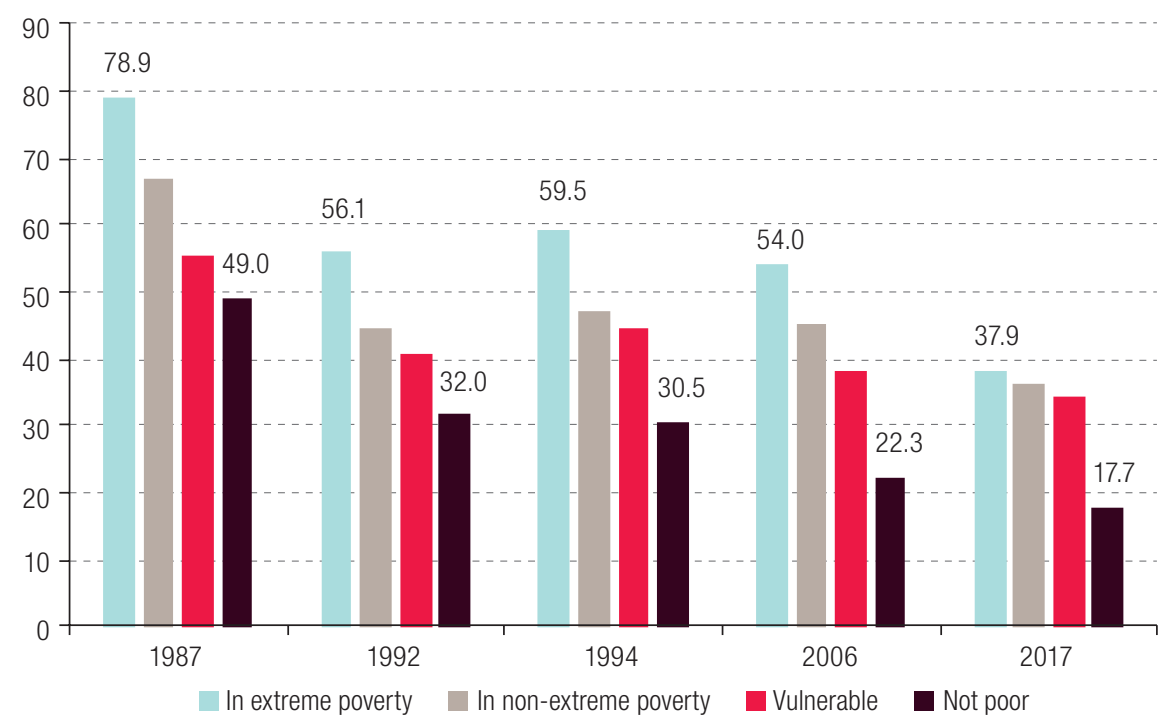

Source: Prepared by the authors, on the basis of figures from the National Institute of Statistics and Censuses (INEC) of Costa Rica. 
As early as 1992, a marked decrease can be seen in the proportion of households with low education, but this was still the situation of half of all poor households. This situation continued until 2006. The positive effects of Costa Rica's increased educational coverage in recent years are more evident in 2017: on average, only 36\% of poor households had low education (many had advanced to the medium education category) and less than one fifth of non-poor households were still in this position.

Figure 5 also shows that education has improved most rapidly at the top and bottom of the income distribution. In fact, the average years' education of the heads of extremely poor households rose from 3.7 in 1987 to 5.9 in 2017, an increase of 60\%. Among households in non-extreme poverty, this average rose from 5.2 to just 5.9 years (the same as for the poorest), while among non-poor households the average years' education of household heads increased from 7.1 years in 1987 to 9.1 years in 2017 , an increase of $29 \%$.

In general, the incidence of poverty is higher in female-headed households, households with older heads and households in rural areas and, particularly, in coastal or border regions. Table 3 summarizes the incidence of monetary poverty for different population groups in the years studied.

\section{Conclusions}

The official method of measuring monetary poverty in Costa Rica presents some obstacles to longterm study of the evolution of poverty, since for various reasons the official series are not comparable between the periods 1987-1999, 2000-2009 and 2010-2017.

One of these reasons concerns the measurement of income and the way this has changed over time, such that a much more accurate and detailed measure of the different incomes of household members is now available.

Furthermore, the construction of the basic food basket and the final calculation of its value in a given year depend on the accuracy with which expenditure data were collected in the income and expenditure survey of the period concerned (which improves with each new application) and, crucially, on the assumption that this representative basket of goods and services remains unchanged for several consecutive years.

Other reasons have to do with methodological and statistical aspects of the data, involving the application of different procedures when there are missing values in the composition of income or adjustment for possible underdeclaration of income by the respondents in each household.

To overcome these limitations, this study reconstructs the household per capita income series in order to make data from the different years comparable (or at least reduce the bias as much as possible), likewise reconstructs the value of the basic food basket (and thence of the poverty line) and evaluates income imputation scenarios and underdeclaration adjustments following INEC methodology, with the aim of studying the evolution of poverty in the period 1987-2017.

By combining the input series described above, it was possible to estimate eight different poverty series, and these are used to demonstrate the declining poverty trend over the period 1987-2017. This finding from the analysis of poverty using series of data that are comparable over time is consistent across the eight proposed poverty series.

Analysis of the poverty series that most closely resembles that obtained with the official INEC methodology shows that, contrary to what is believed, the incidence of poverty did not stagnate between 1994 and 2017, but declined considerably. According to the proposed measure, on average, poverty in Costa Rica decreased from 29\% in 1997 to 23\% in 2007, and then declined further to 19\% in 2017. 
However, this reduction was not sustained over the entire period: there actually was stagnation between 1994 and 2006, after which the downward trend resumed. For this reason, the level of poverty in Costa Rica not only has not stagnated over the last two decades, but has actually fallen by one third compared to 1994. This achievement is all the more important considering that the greatest decrease has been in extreme poverty.

Lastly, three observations can be made about the changes implemented by INEC in the official poverty measurement methodology. First, the objective of the changes is to improve the accuracy of poverty measurement in Costa Rica. Second, the changes were thoroughly explained by INEC. Third, INEC has been careful not to present the official data as if they were a comparable series for the entire period 1997-2017. It has been other entities and individuals that have collected and interpreted the non-comparable data as if they were comparable, despite INEC warnings.

\section{Bibliography}

Acock, C. and D. Demo (2005), "Working with missing values", Journal of Marriage and Family, vol. 67, November. Fernández, A. and R. Del Valle (2017), "Factores explicativos de la reducción de la pobreza por línea de ingreso y de la pobreza multidimensional en Costa Rica del año 2015 al 2016: un estudio de panel", San José, Programa Estado de la Nación.

(2016), "Estimación del Índice de Pobreza Multidimensional de Costa Rica para el período 2005-2015. Sexto Informe del Estado de la Educación", San José, Programa Estado de la Nación.

Hidalgo, J. (2014), Crecimiento económico sin reducción de pobreza: el caso de Costa Rica, CATO Institute. INEC (National Institute of Statistics and Censuses) (2018), Encuesta Nacional de Hogares 2018: creación de variables, San José, (2015a), Encuesta Nacional de Hogares, julio 2015: resultados generales, San José. (2015b), Índice de Pobreza Multidimensional (IPM): metodología, San José, October.

- (2010a), Nueva Encuesta Nacional de Hogares 2010: descripción de los principales resultados, San José.

_ (2010b), "Nueva Encuesta Nacional de Hogares: actualización metodológica para la medición del empleo y la pobreza", Boletín Técnico, San José, November.

(2004), "Medición de la pobreza. Método de la línea de pobreza".

_(2002), Encuesta de Hogares de Propósitos Múltiples: ajustes metodológicos en la EHPM, San José. Medina, F. and M. Galván (2007), "Imputación de datos: teoría y práctica", Statistical Studies series, No. 54 (LC/L.2772-P), Santiago, Economic Commission for Latin America and the Caribbean (ECLAC).

PEN (Programa de Estado de la Nación) (2017), Estado de la nación en desarrollo humano sostenible, San José. Ravallion, M. (2016), The Economics of Poverty: History, Measurement and Policy, Oxford University Press.

Sauma, P. and J. Trejos (2010), "Evolución de la pobreza en Costa Rica: una revisión de las estimaciones 1980-1998", La pobreza en Costa Rica, Economic Science Research Institute (IICE). 


\section{Annex A1}

Table A1.1

Costa Rica: poverty series estimated using a comparable methodology, 1987-2017 (Percentages)

\begin{tabular}{|c|c|c|c|c|c|c|c|c|c|}
\hline \multicolumn{10}{|l|}{ Details of the series: } \\
\hline \multirow[b]{2}{*}{ Income } & & \multicolumn{8}{|c|}{ Multipurpose Household Survey (EHPM) } \\
\hline & & EHPM & EHPM & EHPM & EHPM & EHPM & EHPM & EHPM & EHPM \\
\hline Imputation of missing income & & No & No & No & No & Yes & Yes & Yes & Yes \\
\hline $\begin{array}{l}\text { Value of the basic food } \\
\text { basket and poverty line }\end{array}$ & & 1995 & 1995 & 2011 & 2011 & 1995 & 1995 & 2011 & 2011 \\
\hline $\begin{array}{l}\text { Adjustment for } \\
\text { underdeclaration of income }\end{array}$ & & No & Yes & No & Yes & No & Yes & No & Yes \\
\hline Year & Official & Series 1 & Series 2 & Series 3 & Series 4 & Series 5 & Series 6 & Series 7 & Series 8 \\
\hline 1987 & 29.00 & 40.22 & 29.83 & 52.62 & 40.78 & 35.48 & 25.90 & 47.28 & 36.70 \\
\hline 1988 & 28.40 & 38.96 & 28.23 & 51.43 & 39.64 & 34.38 & 24.30 & 47.13 & 34.93 \\
\hline 1989 & 28.30 & 39.47 & 28.60 & 52.72 & 40.34 & 33.49 & 23.24 & 48.31 & 34.18 \\
\hline 1990 & 27.40 & 37.95 & 27.49 & 50.22 & 37.82 & 35.04 & 24.84 & 49.52 & 36.10 \\
\hline 1991 & 31.90 & 42.65 & 31.91 & 55.75 & 44.29 & 36.09 & 26.59 & 47.46 & 37.19 \\
\hline 1992 & 29.40 & 40.20 & 29.37 & 52.42 & 40.79 & 34.75 & 25.26 & 45.76 & 35.32 \\
\hline 1993 & 23.20 & 33.50 & 23.16 & 45.79 & 34.51 & 27.93 & 19.18 & 38.62 & 28.74 \\
\hline 1994 & 20.00 & 30.01 & 19.96 & 41.22 & 30.50 & 26.51 & 17.53 & 36.87 & 26.94 \\
\hline 1995 & 20.10 & 29.59 & 20.38 & 41.05 & 29.69 & 26.24 & 17.92 & 36.53 & 26.29 \\
\hline 1996 & 21.50 & 31.90 & 21.50 & 43.21 & 31.90 & 28.47 & 19.09 & 38.91 & 28.55 \\
\hline 1997 & 20.70 & 31.12 & 20.71 & 42.89 & 30.98 & 28.54 & 18.58 & 40.07 & 28.56 \\
\hline 1998 & 19.70 & 28.03 & 19.09 & 38.52 & 27.97 & 26.88 & 18.19 & 37.25 & 26.99 \\
\hline 1999 & 20.60 & 31.55 & 20.64 & 43.09 & 31.98 & 28.79 & 18.75 & 39.96 & 29.38 \\
\hline 2000 & 20.60 & 29.08 & 20.57 & 40.49 & 30.72 & 27.35 & 19.31 & 38.50 & 29.05 \\
\hline 2001 & 20.30 & 28.39 & 20.32 & 38.45 & 29.09 & 25.62 & 18.16 & 35.17 & 26.36 \\
\hline 2002 & 20.60 & 28.88 & 20.61 & 39.18 & 29.88 & 25.98 & 18.44 & 35.79 & 26.97 \\
\hline 2003 & 18.50 & 26.06 & 18.54 & 36.53 & 27.12 & 24.42 & 17.31 & 34.62 & 25.48 \\
\hline 2004 & 21.70 & 29.67 & 21.72 & 40.78 & 31.06 & 27.74 & 20.13 & 38.27 & 29.08 \\
\hline 2005 & 21.20 & 29.65 & 21.22 & 38.07 & 28.22 & 28.52 & 20.28 & 36.75 & 27.10 \\
\hline 2006 & 20.20 & 28.21 & 20.24 & 38.09 & 28.58 & 26.94 & 19.28 & 36.60 & 27.30 \\
\hline 2007 & 16.70 & 25.14 & 16.73 & 33.43 & 24.00 & 23.90 & 15.86 & 32.05 & 22.77 \\
\hline 2008 & 17.70 & 26.65 & 17.69 & 32.62 & 22.86 & 24.96 & 16.56 & 30.64 & 21.47 \\
\hline 2009 & 18.50 & 26.76 & 18.49 & 31.07 & 22.16 & 25.96 & 17.86 & 30.21 & 21.46 \\
\hline 2010 & 21.21 & 24.02 & 16.69 & 29.48 & 21.01 & 22.59 & 15.65 & 27.74 & 19.78 \\
\hline 2011 & 21.65 & 24.03 & 17.44 & 28.99 & 21.31 & 22.83 & 16.49 & 27.59 & 20.21 \\
\hline 2012 & 20.57 & 23.65 & 16.23 & 28.34 & 20.48 & 22.10 & 15.05 & 26.50 & 19.13 \\
\hline 2013 & 20.70 & 24.73 & 17.25 & 28.95 & 21.27 & 22.34 & 15.43 & 26.32 & 19.15 \\
\hline 2014 & 22.37 & 27.75 & 20.43 & 31.99 & 23.84 & 23.76 & 17.19 & 27.64 & 20.31 \\
\hline 2015 & 21.73 & 24.97 & 18.60 & 29.56 & 21.74 & 22.97 & 16.99 & 27.33 & 19.96 \\
\hline 2016 & 20.53 & 23.14 & 16.63 & 27.66 & 20.62 & 21.65 & 15.50 & 26.02 & 19.22 \\
\hline 2017 & 20.03 & 22.59 & 15.46 & 26.66 & 19.56 & 21.82 & 14.85 & 25.70 & 18.91 \\
\hline
\end{tabular}

Source: Prepared by the authors, on the basis of data estimated using different combinations of parameters. 


\section{Annex A2}

Table A2.1

Costa Rica: estimation of bivariate regressions to analyse the poverty trend by subperiods, 1987-2017

\begin{tabular}{|c|c|c|c|c|c|c|}
\hline \multicolumn{7}{|c|}{ A. Subperiod 1987-1992 } \\
\hline Series & Coefficient & $\mathrm{p}$-value & $\mathrm{R}^{2}$ & $\begin{array}{c}\text { Statistical } \\
\text { significance }\end{array}$ & $\begin{array}{c}\text { Magnitude } \\
\text { of effect }\end{array}$ & $\begin{array}{c}\text { Overall } \\
\text { significance }\end{array}$ \\
\hline Official & 0.4010 & 0.4307 & 0.1608 & & & No \\
\hline Series 1 & 0.3151 & 0.5430 & 0.0993 & & & No \\
\hline Series 2 & 0.2768 & 0.5954 & 0.0766 & & & No \\
\hline Series 3 & 0.2741 & 0.5991 & 0.0751 & & & No \\
\hline Series 4 & 0.2910 & 0.5758 & 0.0847 & & & No \\
\hline Series 5 & 0.0935 & 0.8601 & 0.0088 & & & No \\
\hline Series 6 & 0.2051 & 0.6966 & 0.0421 & & & No \\
\hline Series 7 & -0.3377 & 0.5126 & 0.1141 & & & No \\
\hline Series 8 & -0.0526 & 0.9211 & 0.0028 & & & No \\
\hline \multicolumn{7}{|c|}{ B. Subperiod 1994-2006 } \\
\hline Series & Coefficient & $\mathrm{p}$-value & $\mathrm{R}^{2}$ & $\begin{array}{c}\text { Statistical } \\
\text { significance }\end{array}$ & $\begin{array}{c}\text { Magnitude } \\
\text { of effect }\end{array}$ & $\begin{array}{c}\text { Overall } \\
\text { significance }\end{array}$ \\
\hline Official & 0.0624 & 0.8395 & 0.0039 & & & No \\
\hline Series 1 & -0.4789 & 0.0978 & 0.2294 & & & No \\
\hline Series 2 & 0.0512 & 0.8682 & 0.0026 & & & No \\
\hline Series 3 & -0.6439 & 0.0175 & 0.4146 & *** & *** & Yes \\
\hline Series 4 & -0.4552 & 0.1181 & 0.2072 & & & No \\
\hline Series 5 & -0.0893 & 0.7717 & 0.0080 & & & No \\
\hline Series 6 & 0.5407 & 0.0564 & 0.2924 & & *** & No \\
\hline Series 7 & -0.2915 & 0.3338 & 0.0850 & & & No \\
\hline Series 8 & -0.0404 & 0.8956 & 0.0016 & & & No \\
\hline \multicolumn{7}{|c|}{ C. Subperiod 1992-1994 } \\
\hline Series & Coefficient & $\mathrm{p}$-value & $\mathrm{R}^{2}$ & $\begin{array}{c}\text { Statistical } \\
\text { significance }\end{array}$ & $\begin{array}{c}\text { Magnitude } \\
\text { of effect }\end{array}$ & $\begin{array}{c}\text { Overall } \\
\text { significance }\end{array}$ \\
\hline Official & -0.9834 & 0.0464 & 0.9672 & *** & $* \star \star *$ & Yes \\
\hline Series 1 & -0.9840 & 0.0456 & 0.9682 & 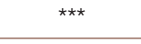 & *** & Yes \\
\hline Series 2 & -0.9834 & 0.0464 & 0.9672 & *** & *** & Yes \\
\hline Series 3 & -0.9947 & 0.0262 & 0.9895 & 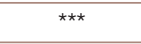 & 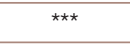 & Yes \\
\hline Series 4 & -0.9918 & 0.0326 & 0.9837 & 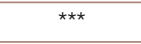 & $* \star \star *$ & Yes \\
\hline Series 5 & -0.9212 & 0.0443 & 0.8486 & *** & *** & Yes \\
\hline Series 6 & -0.9431 & 0.0431 & 0.8895 & 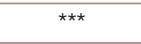 & 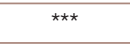 & Yes \\
\hline Series 7 & -0.9298 & 0.0480 & 0.8646 & 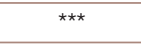 & 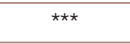 & Yes \\
\hline Series 8 & -0.9390 & 0.0447 & 0.8818 & *** & *** & Yes \\
\hline \multicolumn{7}{|c|}{ D. Subperiod 2006-2017 } \\
\hline Series & Coefficient & $\mathrm{p}$-value & $\mathrm{R}^{2}$ & $\begin{array}{c}\text { Statistical } \\
\text { significance }\end{array}$ & $\begin{array}{c}\text { Magnitude } \\
\text { of effect }\end{array}$ & $\begin{array}{c}\text { Overall } \\
\text { significance }\end{array}$ \\
\hline Official & 0.5662 & 0.0550 & 0.3206 & & *** & No \\
\hline Series 1 & -0.5888 & 0.0440 & 0.3467 & $\star \star \star ~$ & 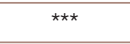 & Yes \\
\hline Series 2 & -0.3017 & 0.3406 & 0.0910 & & & No \\
\hline Series 3 & -0.7915 & 0.0022 & 0.6265 & 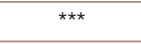 & 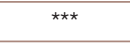 & Yes \\
\hline Series 4 & -0.6861 & 0.0138 & 0.4707 & 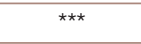 & 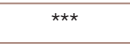 & Yes \\
\hline Series 5 & -0.7650 & 0.0037 & 0.5852 & 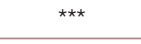 & *** & Yes \\
\hline Series 6 & -0.5339 & 0.0438 & 0.2851 & 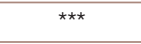 & *** & Yes \\
\hline Series 7 & -0.8538 & 0.0004 & 0.7290 & $\star \star \star ~$ & $\star \star \star *$ & Yes \\
\hline Series 8 & -0.7709 & 0.0033 & 0.5942 & *** & $* * *$ & Yes \\
\hline
\end{tabular}

Source: Prepared by the authors.

Note: ${ }^{\star \star \star}$ The coefficient has statistical significance ( $p$-value of less than 0.05 ) or a considerable effect (an absolute standardized coefficient value of more than 0.5 ). Overall significance is obtained when the coefficient meets both conditions. 